\title{
AN ANALYSIS OF GEOGRAPHIC VARIATION IN THE POGONOMYRMEX OCCIDENTALIS COMPLEX (HYMENOPTERA: FORMICIDAE) ${ }^{1}$
}

\author{
By Steven O. Shattuck \\ Department of Entomology, \\ University of Kansas, \\ Lawrence, Kansas 66045
}

\section{INTRODUCTION}

While examining samples of Pogonomyrmex from southeastern Oregon, I encountered difficulty in segragating the two species reported as occurring in the area, $P$. owyheei Cole and $P$. salinus Olsen (Cole, 1968). Analysis of material from Oregon, Nevada and Utah suggested that the taxonomy of these two forms needed reevaluation. Smith (1953) considered them a single species, but this view was subsequently rejected by Cole (1968).

Cole $(1963,1968)$ described the occidentalis complex as composed of $P$. owyheei and salinus, together with $P$. anzensis Cole, brevispinosus Cole, occidentalis (Cresson), subdentatus Mayr and subnitidus Emery. MacKay (1980) described P. montanus from southern California, bringing the complex to a total of 8 species.

Within the occidentalis complex, the species P. owyheei, salinus, occidentalis, subdentatus and montanus form a distinct, plausibly monophyletic group, united by the cephalic sculpturing, configuration of the antennal scape base, and thoracic sculpturing. This group is referred to here as the occidentalis subcomplex. Because they do not possess this combination of characters, and because monophyly of the occidentalis complex as a whole is uncertain, $P$. anzensis, brevispinosus and subnitidus were excluded from this group and the present study.

\footnotetext{
'Extracted from a thesis submitted to the University of Kansas in partial fulfillment of the degree of Master of Arts. Present address: Department of Entomology, University of California, Davis, CA 95616. Contribution number 1953 from the Department of Entomology, University of Kansas.

*Manuscript received by the editor February 8, 1987.
} 


\section{Materials AND MethodS}

Lending museums and individuals are referred to by the following abbreviations:

AMNH American Museum of Natural History, New York, New York.

LACM Los Angeles County Museum of Natural History, Los Angeles, California.

MDPC Mark B. DuBois, Washington, Illinois.

ORST Oregon State University, Corvallis, Oregon.

UKS University of Kansas, Lawrence, Kansas.

SSPC Steven O. Shattuck, University of California, Davis, California.

UALB University of Alberta, Edmonton, Alberta, Canada.

UCB University of California, Berkeley, California.

UCD University of California, Davis, California.

UCOL University of Colorado Museum, Boulder, Colorado.

UIDM University of Idaho, Moscow, Idaho.

UNSM University of Nebraska State Museum, Lincoln, Nebraska.

USNM United States National Museum, Washington, D.C.

UTST Utah State University, Logan, Utah.

UWYL University of Wyoming, Laramie, Wyoming.

WAST Washington State University, Pullman, Washington.

\section{ANALYSIS OF SPECIMENS}

Every attempt was made to record character data on worker specimens from the entire range of each species and to represent all areas with roughly equal numbers of individuals. In some cases this meant ignoring specimens from densely collected areas, when other areas lacked sufficient samples for analysis. If a single nest was represented by many individuals, three individuals were selected at random and their characteristics recorded. Queens and males were not analyzed because they are poorly represented in collections. Specimens were examined with a dissecting microscope at $75 \times$ magnification. Measurements were made with an ocular micrometer and recorded to the nearest $0.01 \mathrm{~mm}$. The collection sites for specimens studied are listed in Shattuck (1985). 
THE $P$. OCCIDENTALIS SUBCOMPLEX

This group is characterized by the presence of punctures in the interrugal spaces of the head; spines or denticles on the propodeum; postpetiole with a rounded venter; occipital corners with regular, uniform rugae; and frontal lobes only slightly expanded laterally, with a thickened border. The 5 nominal species were examined to find characters that varied geographically within and/or between forms. While many such characters where found, only six varied consistently enough to be of value. Each character was divided into character states (except Scape Index, which was quantified). Since these characters were continuous, division into states was somewhat arbitrary. However, the large variation of each character and the limited number of states recognized in each allowed ready placement of most specimens. Before states were assigned, specimens were compared with "standard" specimens established for each character state. Specimens were initially identified using the concepts of Cole (1968). Many specimens had been previously determined by Cole (primarily from Cole's personal collection, now at LACM), and data were recorded using his identifications. Specimens not readily determined were recorded, but not utilized in the initial analysis. The characters are listed below by their abbreviations, followed by an explanation of the character and a list of the recognized states.

\section{Worker Characters and Character States}

Gaster: Base of the first gastric (fourth abdominal) tergum, near the insertion of the postpetiole, viewed dorsally.

1) Very shiny, with no sculpturing.

2) Very shiny, with faint reticulate sculpturing.

3) Shiny, with reticulate sculpturing.

4) Dull, with moderate reticulate sculpturing.

5) Dull, with heavy reticulate sculpturing.

PetDor: Dorsum of petiolar node viewed dorsally.

1) Entire surface covered with fine punctations, transverse rugae absent.

2) Anterior surface with fine punctations; 1 to 2 weak, transverse rugae superimposed over punctation on posterior quarter. 
3) Anterior surface with fine punctations; 2 to 3 weak to moderate, transverse rugae superimposed over punctation on posterior quarter.

4) Anterior surface with fine punctations; 4 to 5 moderate, transverse rugae superimposed over punctation on posterior half.

5) Rugae (usually 6 to 7) superimposed over punctation on entire surface.

PpDor: Dorsum of postpetiolar node viewed dorsally.

1) Entire surface covered with fine punctations, transverse rugae absent.

2) Anterior surface with fine punctations; 1 to 2 light, transverse rugae superimposed over punctation on posterior quarter.

3) Anterior surface with fine punctations; 3 to 4 light, transverse rugae superimposed over punctation on posterior third.

4) Anterior surface with fine punctations; 5 to 6 moderate, transverse rugae superimposed over punctation on posterior half.

5) Rugae (usually 7 to 9) superimposed over punctation on more than half of surface.

PetVent: Lateral profile of anterior, ventral surface of petiolar peduncle with the petiole, postpetiole and gaster raised dorsally.

1) Tooth absent, entire profile smooth (Figs. 1 and 2).

2) Tooth absent, profile uneven (Figs. 3 and 4).

3) Tooth present but small or indistinct (Figs. 5 and 6).

4) Tooth distinct and moderately developed (Figs. 7 and 8).

5) Tooth well developed and broad (Figs. 9 and 10).

6) Tooth well developed, elongate and narrow (Figs. 11 and 12).

Scape: Base of the antennal scape in lateral view with the antennae parallel to and resting against the dorsal surface of the head.

1) Rounded; flange absent (Figs. 13 and 14).

2) Rounded; flange absent dorsally, but indicated laterally (Figs. 15 and 16).

3) Rounded; flange present, distinctly broader dorsally than ventrally (Figs. 17 and 18).

4) Angular; flange present, slightly broader dorsally than ventrally (Figs. 19 and 20).

5) Angular; flange present, uniform in thickness (Figs. 21 and 22). 
SI: Scape Index $(\mathrm{SL} \times 100) /(\mathrm{HW})$ where:

$\mathrm{SL}$ is the scape length (maximum length of the scape exclusive of the radicle).

HW is the head width (maximum width of the head in full face (dorsal) view, exclusive of the eyes).

\section{Analysis of Character States}

In this section the species concepts of Cole (1968) are maintained. Each character is considered separately by species, or pair of species where applicable. In the next section each species is considered individually and specific taxonomic changes proposed. Data are pooled and analyzed by county within each species or group of species. Figures 23 through 36 represent the character distribution data graphically. Each bar graph represents pooled data for one county, with the vertical axis representing frequency and the horizontal axis representing the character states (state 1 on the left, state 5 or 6 on the right). The number of specimens represented is indicated and each graph is located at the approximate center of the area pooled.

\section{GASTER}

Pogonomyrmex occidentalis possesses Gaster states 1, 2 and 3 (Table 1) distributed randomly, with all states occurring in all areas of the range in roughly equal proportions (Fig. 23).

Cole (1968) stated that in P. salinus the "base of dorsum of first gastric segment [is] frequently densely and coarsely punctate and opaque, sometimes only very finely punctate or densely shagreened and subopaque or shining," while for $P$. owyhee $i$ it is "as in occidentalis," which has "light to moderate shagreening which does not dull the shining surface". These characterizations were confirmed in the present study. The gaster of $P$. salinus may possess any of the states, with state 1 the least common and state 5 the most common (Table 1). In $P$. owyheei, most specimens possess states 1,2 or 3 , with states 4 and 5 represented in lower frequencies (Table 1). Thus while this character is of some value in distinguishing these two forms, there is frequent overlap with $80 \%$ of the $P$. owyheei and $44 \%$ of the $P$. salinus specimens showing Gaster states 2 or 3 . 
Table 1. Table of Character State Frequencies*

\begin{tabular}{|c|c|c|c|c|c|}
\hline \multirow{2}{*}{$\begin{array}{c}\text { Character } \\
\text { /State } \\
\text { Gaster }\end{array}$} & \multicolumn{5}{|c|}{ Taxa } \\
\hline & P. mon & P. occ & P. owy & P. sal & P. sub \\
\hline 1 & 0 & 36 & 10 & 3 & 24 \\
\hline 2 & 50 & 62 & 54 & 22 & 51 \\
\hline 3 & 50 & 2 & 26 & 22 & 24 \\
\hline 4 & 0 & 0 & 2 & 12 & 0 \\
\hline 5 & 0 & 0 & 8 & 42 & 0 \\
\hline \multicolumn{6}{|l|}{ PetDor } \\
\hline 1 & 0 & 12 & 19 & 2 & 6 \\
\hline 2 & 0 & 37 & 26 & 8 & 0 \\
\hline 3 & 0 & 37 & 32 & 6 & 26 \\
\hline 4 & 0 & 11 & 9 & 16 & 8 \\
\hline 5 & 100 & 4 & 14 & 69 & 59 \\
\hline \multicolumn{6}{|l|}{ PetVent } \\
\hline 1 & 0 & 21 & 43 & 29 & 2 \\
\hline 2 & 50 & 44 & 33 & 27 & 6 \\
\hline 3 & 50 & 17 & 19 & 20 & 9 \\
\hline 4 & 0 & 12 & 2 & 13 & 9 \\
\hline 5 & 0 & 3 & 3 & 11 & 28 \\
\hline 6 & 0 & 2 & 0 & 2 & 46 \\
\hline \multicolumn{6}{|l|}{ PpDor } \\
\hline 1 & 0 & 74 & 52 & 13 & 16 \\
\hline 2 & 0 & 22 & 28 & 11 & 10 \\
\hline 3 & 0 & 2 & 13 & 38 & 43 \\
\hline 4 & 0 & 1 & 2 & 14 & 12 \\
\hline 5 & 100 & 0 & 5 & 25 & 18 \\
\hline \multicolumn{6}{|l|}{ Scape } \\
\hline 1 & 0 & 0 & 21 & 76 & 11 \\
\hline 2 & 0 & 0 & 10 & 13 & 6 \\
\hline 3 & 0 & 12 & 32 & 5 & 19 \\
\hline 4 & 50 & 35 & 10 & 3 & 13 \\
\hline 5 & 50 & 53 & 27 & 3 & 52 \\
\hline Sample Size: & 4 & 343 & 261 & 148 & 128 \\
\hline
\end{tabular}

*All values are percentages. Taxa abbreviations are: $P$. mon $=P$. montanus, $P$. occ $=$ $P$. occidentalis, $P$. owy $=P$. owyheei, $P$. sal $=P$. salinus, $P$. sub $=P$. subdentatus.

The geographic distribution of this character supports Cole's (1968) northern limit for P. salinus as southern Oregon (Lake, Harney and Malheur counties), but indicates $P$. owyheei as occurring throughout Nevada and Utah (Fig. 24) rather than northern Nevada and Utah northward. 
P. montanus has Gaster states 2 and 3 in equal proportions (Table $1)$, but shows no geographic pattern. P. subdentatus possesses states 1,2 and 3 , with state 3 the most common (Table 1); the states are distributed randomly throughout the range of the species.

\section{Dorsum of Petiole and Postpetiole (PetDor ANd PpDor)}

All character states of PetDor are represented in P. occidentalis (Table 1). The character PpDor is represented by states 1, 2, 3 and 4 (Table 1). Both of these characters show random geographic distribution; all states occur in all areas of the range of $P$. occidentalis (Figs. 25 and 26).

Cole (1968) described the dorsum of the petiolar and postpetiolar nodes of $P$. salinus as "generally covered with numerous, strong, wavy, closely spaced, subparallel, usually transverse rugae" (PetDor states 4 and 5; PpDor states 4 and 5). In P. owyheei he described these structures as "not covered with numerous, strong, wavy, closely spaced, subparallel, transverse rugae, the nodes with or without irregular rugae, rugulae or striae" (PetDor states 1, 2 and 3; PpDor states 1 and 2). In this study all states of PetDor and PpDor were found to occur in both $P$. salinus and $P$. owyheei (Table 1) in frequencies which agree loosely with Cole's (1968) descriptions of these species. $P$. salinus possesses primarily PetDor states 4 and 5 (85\%), but substantial numbers have states 1 and $2(10 \%)$. Similarly, PpDor states 4 and 5 occur in $39 \%$ of the specimens, but states 1 and 2 occur in 24\%. In P. owyheei, PetDor states 1, 2 and 3 account for $77 \%$ of the specimens, but states 4 and 5 occur in $23 \%$. PpDor states 1 and 2 are represented in $80 \%$ of the specimens, while states 4 and 5 are only found in $7 \%$. The broad overlap in the states of these characters makes them of limited value in discriminating these forms.

The geographic distribution of the states of these characters shows a pattern similar to that of the Scape states: decreasing frequencies of states 1 and 2 and increasing frequencies of states 4 and 5 from north to south, with a broad area of overlap from central Oregon into northern Nevada (Figs. 27 and 28). PpDor state 1 is found as far south as Washington County, Utah (100\%), while state 5 occurs only as far north as Harney and Lake counties, Oregon 

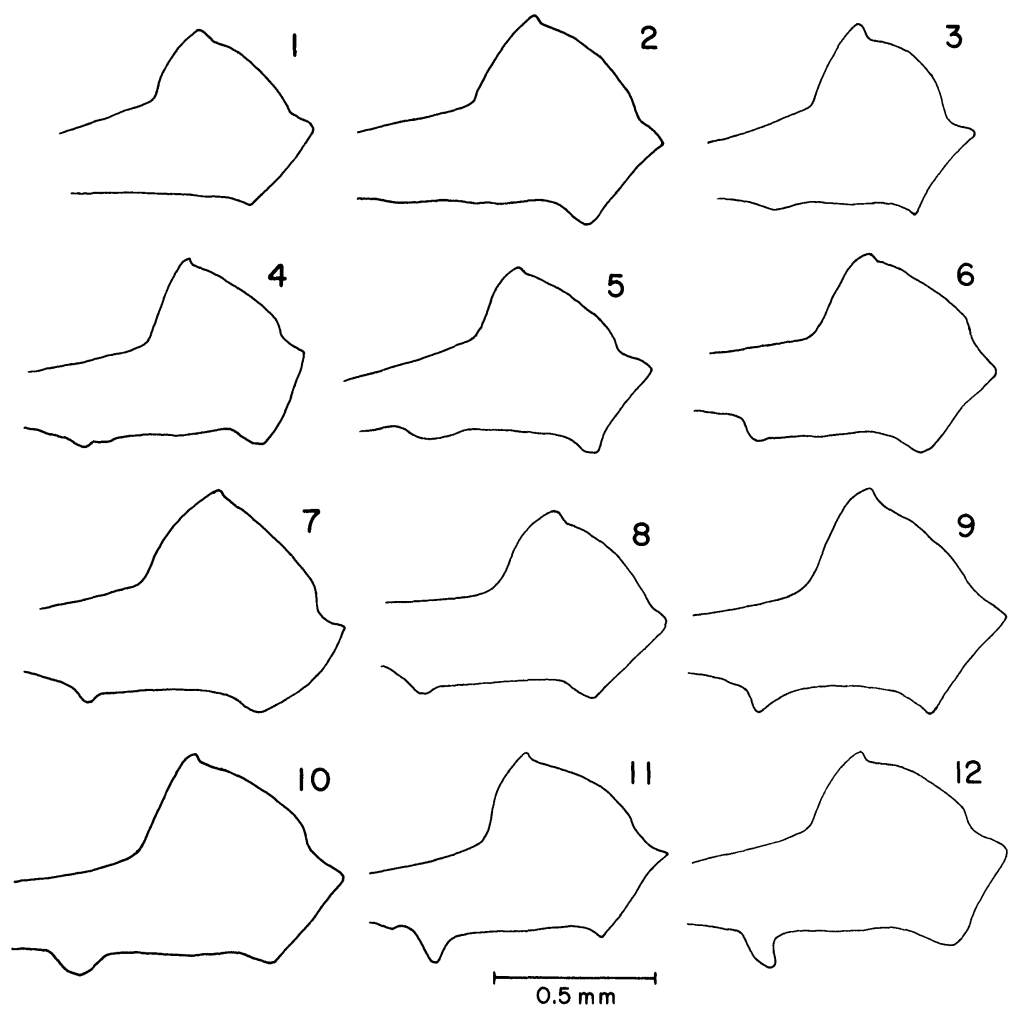

Figs. 1-12, states for ventral surface of petiolar peduncle (PetVent). Fig. 1, state 1 ( $P$. salinus, $17 \mathrm{mi} \mathrm{S}$. Eureka, Eureka Co., Nevada). Fig. 2, state 1 ( $P$. salinus, Lovelock, Pershing Co., Nevada). Fig. 3, state 2 ( $P$. salinus, Aurora, Mineral Co., Nevada). Fig. 4, state 2 ( $P$. salinus, Reno, Nevada). Fig. 5, state 3 ( $P$. salinus, 6 mi E Wells, Elko Co., Nevada). Fig. 6, state 3 ( $P$. subdentatus, Gonzales, Monterey Co., California). Fig. 7, state 4 ( $P$. salinus, Wabuska, Lyon Co., Nevada). Fig. 8, state 4 (P. subdentatus, Russell Reservation, Contra Costa Co., California). Fig. 9, state 5 ( $P$. subdentatus, $18 \mathrm{mi} \mathrm{S}$. Ravendale, Lassen Co., California). Fig. 10, state 5 (P. salinus, Lovelock, Pershing Co., Nevada). Fig. 11, state 6 ( $P$. subdentatus, Santa Cruz Island, Santa Barbara Co., California). Fig. 12, state 6 ( $P$. subdentatus, Gonzales, Monterey Co., California).

( $16 \%$ and $14 \%$ respectively). PetDor state 1 , however, occurs only as far south as Lassen County, California (33\%) and Elko County, Nevada (9\%), while state 5 extends northward into Lake (33\%), Harney (28\%) and Malheur (20\%) counties, Oregon, and Elmore 
County (33\%), Idaho. Thus neither of these characters fully supports the distributional boundaries of $P$. salinus and $P$. owyheei cited by Cole (1968): PetDor indicates the northern extent of $P$. salinus as central Oregon rather than southern Oregon, while the southern boundary of $P$. owyheei (northern California and Nevada) is supported; PpDor supports the northern extent of $P$. salinus as southern Oregon but indicates $P$. owyheei as occurring throughout Nevada rather than limited to the northern portions.

All specimens of $P$. montanus have PetDor state 5 and PpDor state 5 (Table 1), thus showing no geographic variation. $P$. subdentatus does show variation in these characters, with PetDor states 1 , 3, 4 and 5 represented as well as all PpDor states (Table 1). However, this variation is distributed randomly throughout the range of the species (Figs. 29 and 30).

\section{Venter of Petiolar Peduncle (PetVent)}

In P. occidentalis, all states of PetVent are represented (Table 1). This agrees with the findings of Cole (1968), except for the presence of a prominent process (states 5 and 6 ) in $24 \%$ of the specimens from Dawson, Roosevelt and Rosebud counties, Montana.

Pogonomyrmex owyheei possesses the first five states of PetVent in decreasing frequency and lacks the sixth state (Table 1). P. salinus shows a similar trend, but possesses all states (Table 1) and a higher proportion of individuals with higher states. $P$. subdentatus has all states represented but in increasing frequency from state 1 to state 6 (Table 1). The presence of a large process on the venter of the petiolar peduncle is often used as a diagnostic character for $P$. subdentatus (Creighton, 1950; Cole, 1968) and the presence of states 4, 5 and 6 in populations of $P$. salinus in western Nevada may indicate gene flow between these two species. States 4,5 and 6 occur in $P$. salinus only in or near areas containing populations of $P$. subdentatus (south central Oregon, western Nevada), while in all other areas P. salinus exhibits states 1, 2 or 3 (Fig. 31). Other characteristics of $P$. subdentatus (cephalic sculpturing, propodeal spine development, thoracic profile) do not appear in western Nevada populations of $\boldsymbol{P}$. salinus, indicating only limited or no gene flow between $P$. salinus and P. subdentatus. There is a weak trend for state 1 to increase and states 2 and 3 to decrease as one moves outward from northwestern Nevada. 

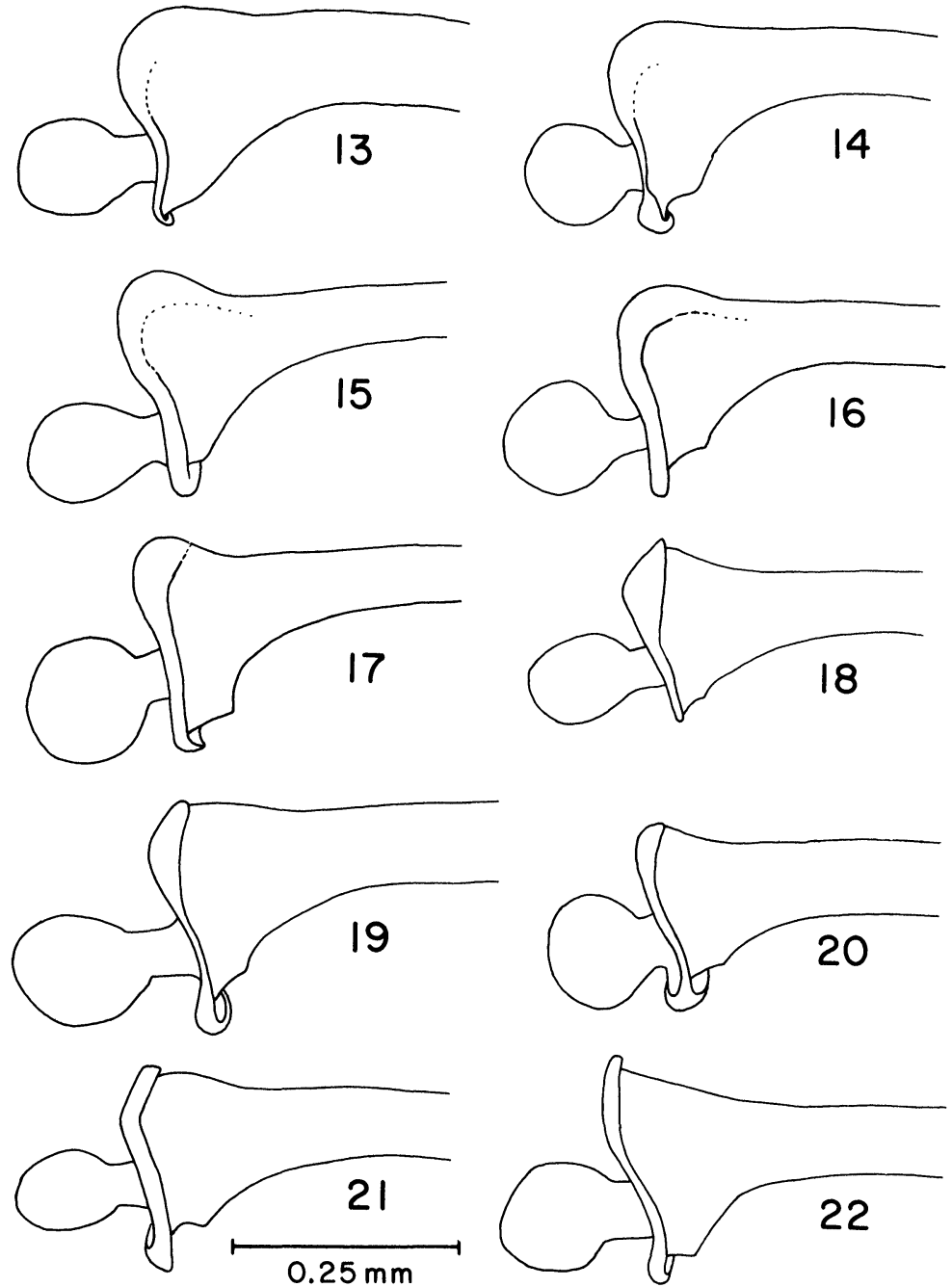

Figs. 13-22, states for base of antennal scape (Scape). Fig. 13, state 1 (P. salinus, $2 \mathrm{mi} \mathrm{N}$ Montello, Elko Co., Nevada). Fig. 14, state 1 ( $P$. salinus, Sulphur, Humboldt Co., Nevada). Fig. 15, state 2 ( $P$. salinus, T14N R6E, White Pine Co., Nevada). Fig. 16, state 2 ( $P$. salinus, T18N R64E, White Pine Co., Nevada). Fig. 17, state 3 (P. salinus, Raft River Narrows, Cassia Co., Idaho). Fig. 18, state 3 (P. salinus, Montgomery Pass, Mineral Co., Nevada). Fig. 19, state 4 (P. subdentatus, Davis, Yolo Co., California). Fig. 20, state 4 ( $P$. salinus, Kelton Junction, Box Elder Co., Utah). Fig. 21, state 5 ( $P$. subdentatus, $18 \mathrm{mi}$ S Ravendale, Lassen Co., California). Fig. 22, state 5 ( $P$. occidentalis, Ogden, Weber Co., Utah). 
Pogonomyrmex montanus was found to possess states 2 and 3 in equal proportions, a finding which agrees with the original description (MacKay, 1980).

\section{SCAPE}

The scape base of $P$. occidentalis varies from state 3 to state 5 (Table 1) but shows no geographic pattern, with the states occurring in all parts of the range in roughly equal proportions (Fig. 32). This agrees well with the observations of Cole (1968), although he did not recognize the extent of the variation.

All Scape states occur in $P$. subdentatus (Table 1). States 1 and 2, and $90 \%$ of the state 3 records occur in western Nevada; state 4 occurs equally in California and Nevada, and state 5 occurs primarily in California and Oregon, with a few (14\%) records from Nevada (Fig. 33). Cole (1968) asserted that the scape base of $P$. subdentatus is equivalent to state 5 , and distinct from that of $P$. salinus. This observation was apparently in error because some specimens found to have states 1 and 2 in this study were determined by Cole as $P$. subdentatus (specimens now in LACM).

Cole (1968) describes the scape base of $P$. salinus as "evenly and broadly rounded", while that of $P$. owyheei is "not evenly and broadly rounded." Cole's figures show the scape base of $P$. salinus as evenly rounded dorsally, without any trace of a basal flange, while that of $P$. owyheei has a distinct basal flange dorsally. Two aspects of this character are inconsistent with these statements. First, the geographic distributions of these character states are not concordant with the geographic distribution of the species supposed to possess them; and second, material determined by Cole (from LACM) does not always possess the appropriate states.

The geographic distribution of these character states does not agree with the distribution of $P$. owyheei and $P$. salinus as stated by Cole (1968). Scape state 1 (indicative of $P$. salinus) occurs primarily in Nevada, but has also been found at Twin Falls, Montana; Redmond, Cline Falls State Park, Summer Lake, and Hermiston, Oregon; and Burlington and Greybull, Wyoming (Fig. 34). Scape state 5 (indicative of $P$. owyheei) occurs in all areas expected except the northwestern portions of its range (Washington, British Columbia) where only Scape state 3 occurs. Scape state 5 occurs outside 
the putative range of $P$. owyheei at a site 3 miles southeast of Rowland, Nevada; at Bridgeport, California; and at several localities in Washington County, Utah. This would indicate that $P$. salinus extends north into central Oregon (Lake and Deschutes counties) with small populations farther north and east, while $P$. owyheei has populations in eastern California (Lassen and Mono counties) and southwestern Utah (Washington County).

The second inconsistency involves specimens determined by Cole. Numerous specimens with Scape state 1 were determined as $P$. owyheei by Cole. These were collected in Nevada (Elko and Washoe counties), Oregon (Harney and Umatilla counties), and Wyoming (Big Horn County). Scape state 5 was found in two nest series determined as $P$. salinus by Cole from northern California (11.5 miles south of Termo and 18 miles south of Ravendale, Lassen County). These determinations show that Cole either allowed considerable variation in this character, or utilized other characters (alone or in combination) to identify these forms.

The $P$. montanus collections show no geographic variation in this character.

\section{SCAPE INDEX (SI)}

The SI of $P$. occidentalis varies from 65 to 78 , with a mean of 66.9. It shows a weak cline, with low values in the eastern part of the range (Colorado, Kansas) and high values in the western portions (Utah, Nevada) (Fig. 35).

Cole (1968) found the SI of $P$. owyheei to vary from 83.0 to 100.0 , while that of $P$. salinus varied between 83.5 and 84.0. A random sample of material determined by Cole (from LACM) was measured, and the SI varied from 69.0 to 79.0 (mean $=73.8$, sd. $=2.20$, $\mathrm{n}=32$ ) in $P$. owyheei and 70.0 to 84.0 (mean $=76.1$, sd. $=3.18$, $\mathrm{n}=33)$ in $P$. salinus. The discrepancy between these measurements and those of Cole (1968) may be caused by differences in measurement techniques. Cole's range of SI values was greater for $P$. owyheei than for $P$. salinus, while material now available shows the opposite. This may be due to a small sample of $P$. salinus in Cole's study. Although the broad overlap in the ranges of SI values makes this character of little value in discriminating the taxa, the means are significantly different $(t=3.35, p=0.0014)$. 


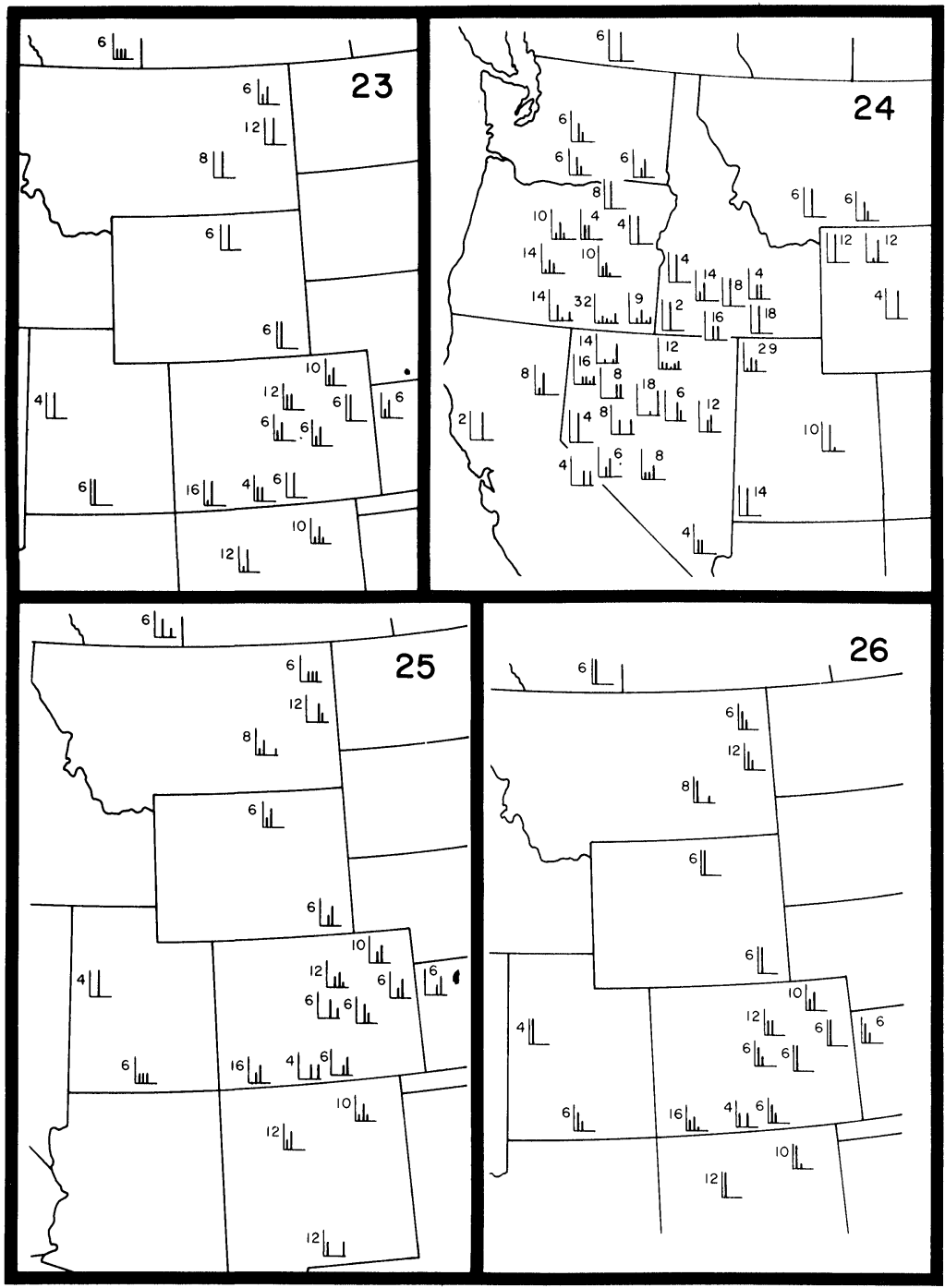

Figs. 23-26, distribution of character states. Fig. 23, Gaster states for P. occidentalis. Fig. 24, Gaster states for P. salinus and P. owyheei. Fig. 25, PetDor states for $P$. occidentalis. Fig. 26, PpDor states for P. occidentalis. 
Geographically, this difference may be explained by the presence of large scape values in southern Nevada (Fig. 36). Over the northern portions of the range of these two forms the SI values vary between 70 and 82 , with a mean of 74.2 , while in the southern portions (Clark, Eureka, Nye, White Pine counties, Nevada, and Mono County, California) SI varies from 74 to 84, with a mean of 77.8. This trend, however, is weak with large SI values occurring in some northern populations (i.e. SI $=82$ in Lake County, Oregon) and small values in some southern populations ( $\mathrm{SI}=66$ in Washington County, Utah).

\section{TAXonomic Conclusions}

\section{P. montanus MacKay}

P. montanus MacKay, 1980: 151 (W, M, F). Type Loc.: Hanna Flat, 4 km NW Fawnskin, San Bernardino Co., California, USA.

P. montanus is known only from the San Bernardino Mountains of southern California. It is retained as a full species in this study.

\section{P. occidentalis (Cresson)}

Myrmica occidentalis Cresson, 1865: 426 (W, F). Type Loc.: Colorado Territory, USA.

Myrmica seminigra Cresson, 1865: 427 (M). Type Loc.: Colorado Territory, USA. (Synonymy by Forel, 1886: 42.)

P. opaciceps Mayr, 1870: 971 (W). Type Loc.: New Mexico, USA. (Synonymy by Forel, 1886: 42.)

P. occidentalis ruthveni Gaige, 1914: 93 (W, M, F). Type Loc.: James Canyon, Elko Co., Nevada, USA. (Synonymy by Olsen, 1934: 507.)

P. occidentalis utahensis Olsen, 1934: 509 (W, M, F). Type Loc.: Zion National Park, Utah, USA. (Synonymy by Cole, 1968: 95.)

P. occidentalis may be separated from all other species in the complex by the offset tooth at the basal angle of the mandible. As demonstrated by Colley (1962), all other known characters occur in $P$. owyheei, as well as $P$. salinus, and are of no value in distinguishing this species. In no case did I find intermediate specimens between this species and $P$. owyheei or $P$. salinus, contrary to the findings of Allred (1982). The characters used in this study further support the distinctness of this species. The characters Gaster, PetDor, PpDor and Scape show a moderate degree of variation, but a 
random geographic distribution. This differs from closely related species in which clines are seen in many of these characters. Since there is a broad region of overlap (western Utah, Nevada, eastern California) of $P$. occidentalis and several other species, interbreeding would be expected to produce clinal patterns in both species involved. This was not observed in regions where $P$. occidentalis and related species are sympatric.

\section{P. salinus Olsen}

P. salinus Olsen, 1934: 510 (W). Type Loc.: near Soda Springs, Bridgeport, Mono Co., California, USA.

P. occidentalis owyheei Cole, 1938: 240 (W, F). Type Loc.: Indian Cove, near Hammett, Elmore Co., Idaho, USA. (New Synonymy)

Cole (1968) considered $P$. owyheei and P. salinus as distinct species and gave little discussion to the matter. The present study shows that many characters have clinal patterns not in support of Cole's view. The gaster shows a clinal pattern with smooth states (1 and 2) in the north and smooth and rough states $(3,4$ and 5$)$ in the south. This partly supports the distinctness of $P$. salinus by limiting it to the southern portions of the range, but does not support the notion that $P$. owyheei occurs only in the north. PpDor shows a similar clinal pattern, with greater variation in the southern portions of the range and less variation in the north. PetDor differs from both of these characters in that it shows $P$. salinus-like states as occurring north into central Oregon, while $P$. owyheei-like states do not occur south of northern Nevada. The scape also incorrectly indicates the distributions of these two forms. As determined by the shape of the scape, $P$. salinus would extend northward into central Oregon, while $P$. owyhee $i$ would extend southward into east-central California and southern Utah.

Many specimens determined by Cole (primarily in LACM) suggest that color and distribution played a role in his actual determinations: dark specimens from southern areas were identified as $P$. salinus while light-colored individuals from northern areas were identified as $P$. owyheei. Since color is somewhat subjective and difficult to quantify I made no attempt to do so but did record it while making determinations. Cole (1968) mentioned color in his treatment of these species but did not use it as a distinctive character in his keys or discussion. 


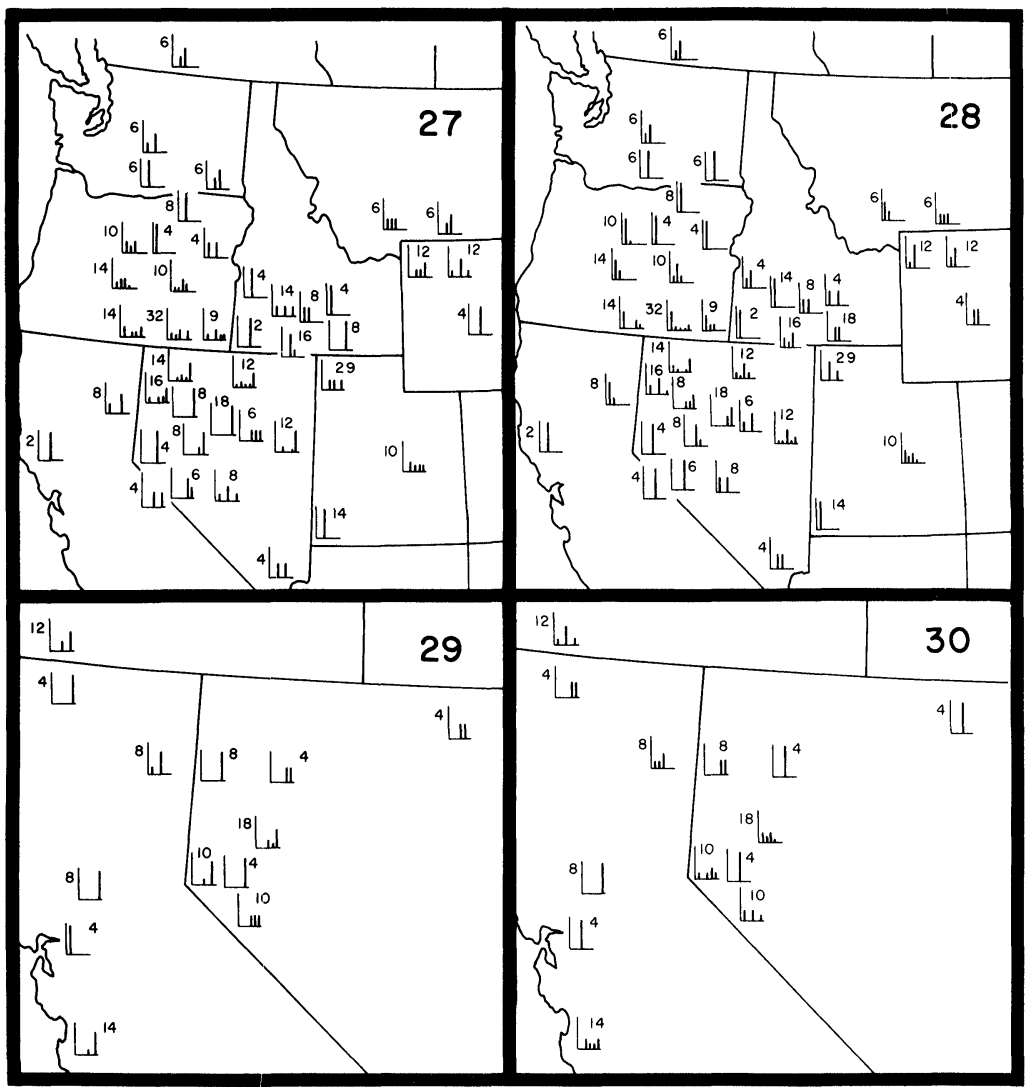

Figs. 27-30, distribution of character states. Fig. 27, PetDor states for $P$. salinus and $P$. owyheei. Fig. 28, PpDor state for $P$. salinus and $P$. owyheei. Fig. 29, PetDor states for $P$. subdentatus. Fig. 30, PpDor states for P. subdentatus.

It is clear that $P$. owyheei represents northern populations of a single, variable species and is therefore a synonym of $P$. salinus. As can be seen from Figures 24, 27, 28, 31, 34 and 36, there are no distinct and consistent steps in the clines of the characters studied. This makes the recognition of subspecies difficult and of little value in this species. 


\section{P. subdentatus Mayr}

P. subdentatus Mayr, 1870: 971 (W). Type Loc.: California, USA.

$P$. subdentatus has been considered a full species since its original description. The usual characters given for its identification are the presence of a ventral process on the petiolar peduncle (Creighton, 1950), the arched profile of the thoracic dorsum and the cephalic sculpturing (Cole, 1968). The cephalic sculpturing shows only a small amount of variation among the species and has not been used in the present study. The process on the venter of the petiolar peduncle shows variation within and between species and was quantified as character PetVent. The arched profile of the alitrunk is unique to $P$. subdentatus.

The presence of a process on the venter of the petiolar peduncle and Scape states 1 and 2 in $P$. subdentatus and sympatric populations of $P$. salinus may cause confusion of some samples of these species, but the arched thoracic dorsum and reduced propodeal spines are characteristic of $P$. subdentatus. The presence of a PetVent process and Scape states 1 and 2 in some sympatric populations of $P$. salinus may indicate gene flow between these two species, but the lack of other characters of $P$. subdentatus in these populations distinguishes the species clearly and suggests no gene flow between them. Further study will be necessary to resolve this inconsistency.

\section{KeY TO THE SPECIES OF THE PogonomyRMEX ocCIDENTALIS COMPLEX, Based on Workers.}

1a. Mandible with 6 teeth; venter of postpetiole with a strong, triangular tooth ...................... anzensis

1b. Mandible with 7 teeth; venter of postpetiole rounded, without a

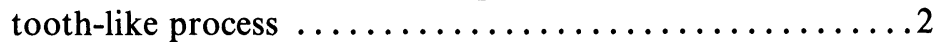

2a. Interrugal spaces of head smooth and shiny, without punctation; dorsum of petiolar node without transverse rugae ..... ............................... P. subnitidus

$2 b$. Interrugal spaces of head densely punctate and opaque, with a beaded appearance; dorsum of petiolar node variable, but often with at least 1 ruga present posteriorly............ 


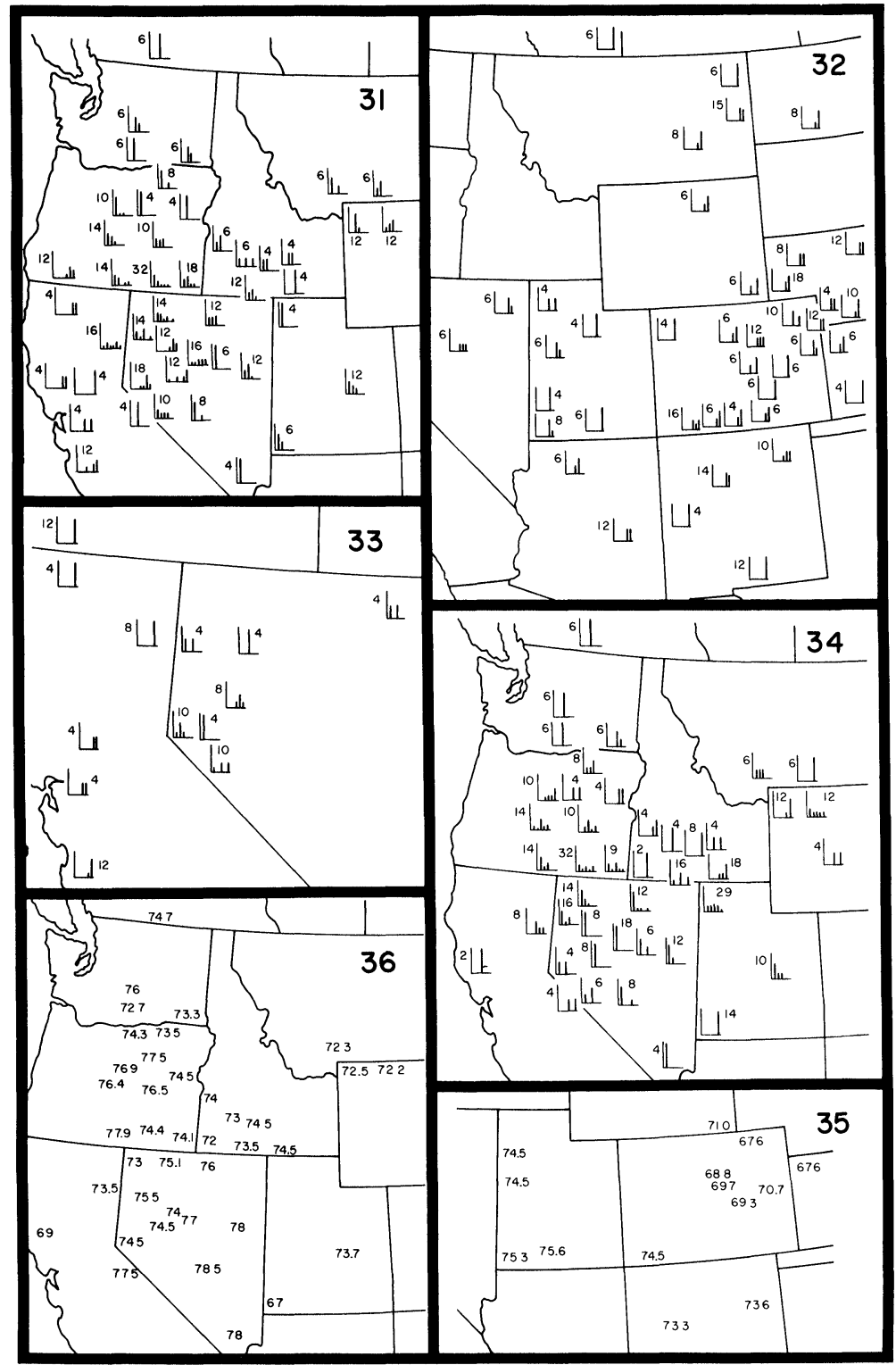

Figs. 31-36, distribution of character states. Fig. 31, PetVent states for P. salinus, $P$. owyheei and $P$. subdentatus. Fig. 32, Scape states for $P$. occidentalis. Fig. 33, Scape states for $P$. subdentatus. Fig. 34, Scape states for $P$. salinus and $P$. owyheei. Fig. 35, SI values for $P$. occidentalis. Fig. 36, SI values for $P$. salinus and P. owyheei. 
3a. Propodeal spines absent or, if present, shorter than the distance between their bases; venter of petiolar peduncle smooth, without a process; frontal lobes expanded laterally, without a thickened border ................. P. brevispinosus

3b. Propodeal spines distinctly longer than the distance between their bases or, if shorter or absent, then venter of petiolar peduncle may possess a broad and short to narrow and long process; frontal lobes slightly expanded laterally, with a thickened border (occidentalis subcomplex) ...........4

4a. Basal tooth of mandible offset, causing basal margin of mandible to form an angle medially .......P. occidentalis

4b. Basal tooth of mandible not offset, basal margin of mandible even over its entire length......................

5a. Propodeal spines absent or, if present, distinctly shorter than the distance between their bases; thoracic profile arched, with an angle present near the mesopropodeal suture; majority of workers from a given nest series with a well developed process or tooth on the venter of petiolar peduncle .............. P. subdentatus

5b. Propodeal spines longer than the distance between their bases or, if shorter, then without a process or tooth on the venter of the petiolar peduncle; thoracic profile flat, without an angle near the mesopropodeal suture; venter of the petiolar peduncle generally without a process (present in some populations from western Nevada and eastern California).............6

6a. Base of antennal scape angular, with flange present, and dorsum of petiolar and postpetiolar nodes with 5 or more moderate to heavy rugae superimposed over punctations on posterior half. (Known only from the San Bernardino Mountains of California) ........................ montanus

6b. Base of antennal scape rounded or angular; if angular, then dorsum of petiolar and postpetiolar nodes with less than 5 moderate rugae on posterior half. (Widespread)...........

P. salinus

\section{SUMMARY}

The occidentalis subcomplex of Pogonomyrmex is defined as a subgroup of Cole's (1968) “occidentalis complex," consisting of five nominal species. Six taxonomically significant morphological characters are quantified and recorded from throughout the ranges of 
each species. The character states are mapped to reveal clinal patterns and this information is used to help with systematic decisions.

$P$. occidentalis differs from all others in the subcomplex by its unique mandibular structure. The states of 5 of 6 characters studied show random geographic distribution and are of no value in differentiating this species from others. $P$. owyheei is a synonym of $P$. salinus (new synonymy). No single character or combination of characters could be found to separate these two forms. P. subdentatus possesses several unique, although subtle, characters and is retained as a full species. P. montanus is also maintained as a full species.

\section{ACKNOWLEDGMENTS}

I wish to thank Dr. Charles D. Michener for his assistance and guidance during this research. I also thank Drs. G. W. Byers, P. D. Ashlock and P. S. Ward for comments on the manuscript. The constant support and encouragement of M. K. Smith is gratefully acknowledged. Publication costs were provided in part by the Department of Entomology, University of California, Davis.

\section{Literature Cited}

AllRed, D. M.

1982. Ants of Utah. Great Basin Nat. 42: 415-511.

Cole, A. C., Jr.

1938. Suggestions concerning taxonomic nomenclature of the hymenopterous family Formicidae, and descriptions of three new ants. Amer. Mid. Nat. 19: $236-241$.

1963. A preliminary synopsis of the subgenera and complexes of the ant genus Pogonomyrmex Mayr in North America. Symposia Genetica et Biologica Italica 12: 51-59.

1968. Pogonomyrmex Harvester Ants: A study of the genus in North America. Univ. of Tennessee Press, Knoxville. 222 p.

Colley, E. A.

1962. Internidal and intranidal variations of external morphological characteristics of the worker caste of Pogonomyrmex occidentalis (Cresson) (Hymenoptera: Formicidae). Unpubl. MS Thesis, Univ. of Tennessee, Knoxville. 80 p.

Creighton, W. S.

1950. Ants of North America. Bull. Mus. Comp. Zool. 104: 1-585.

Cresson, E. T.

1865. Catalogue of Hymenoptera in the collection of the Entomological Society of Philadelphia from Colorado Territory. Proc. Entomol. Soc. Philadelphia 4: 242-313, 426-488. 
Forel, A.

1886. Especies nouvelles de Fourmis Americaines. Ann. Soc. Entomol. Belgique 30: $38-49$.

Gaige, F. M.

1914. Description of a new subspecies of Pogonomyrmex occidentalis (Cresson) from Nevada. Proc. Biol. Soc. Washington 27: 93-96.

MACKAY, W. P.

1980. A new harvester ant from the mountains of southern California (Hymenoptera: Formicidae). Southwestern Nat. 25: 151-156.

MAYR, G.

1870. Neue Formiciden. Verh. Zool.-bot. Ges. Wien 20: 939-996.

OLSEN, O. W.

1934. Notes on the North American harvesting ants of the genus Pogonomyrmex Mayr. Bull. Mus. Comp. Zool. 77: 493-514.

Shattuck, S. O.

1985. An analysis of geographic variation in the Pogonomyrmex occidentalis complex (Hymenoptera: Formicidae). Unpubl. M.A. Thesis, University Sмiтh, M. R. of Kansas, Lawrence. $100 \mathrm{p}$.

1953. Pogonomyrmex salinus Olsen, a synonym of Pogonomyrmex occidentalis (Cress.) (Hymenoptera: Formicidae). Bull. Brooklyn Entomol. Soc. 48: 131-132. 

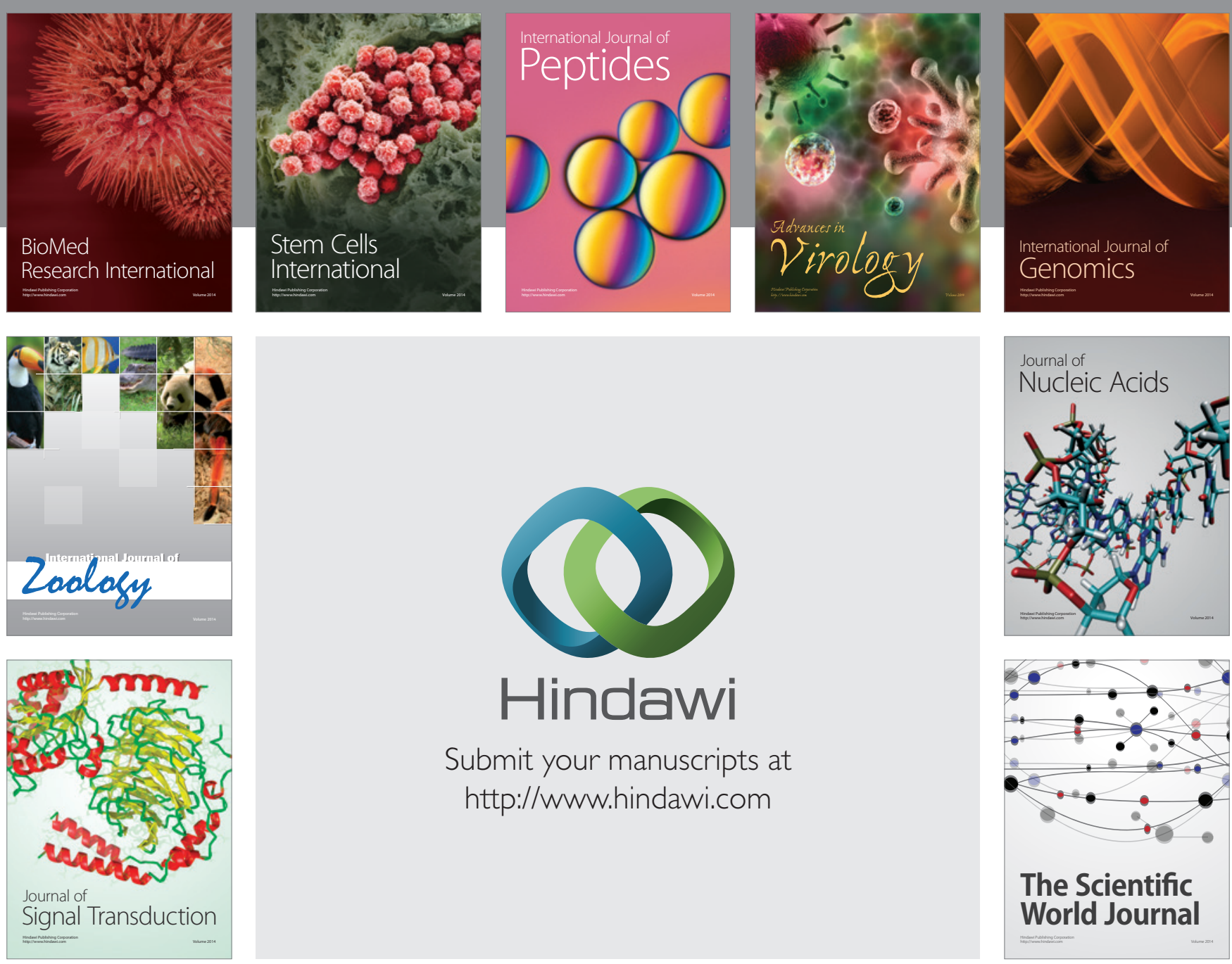

Submit your manuscripts at

http://www.hindawi.com
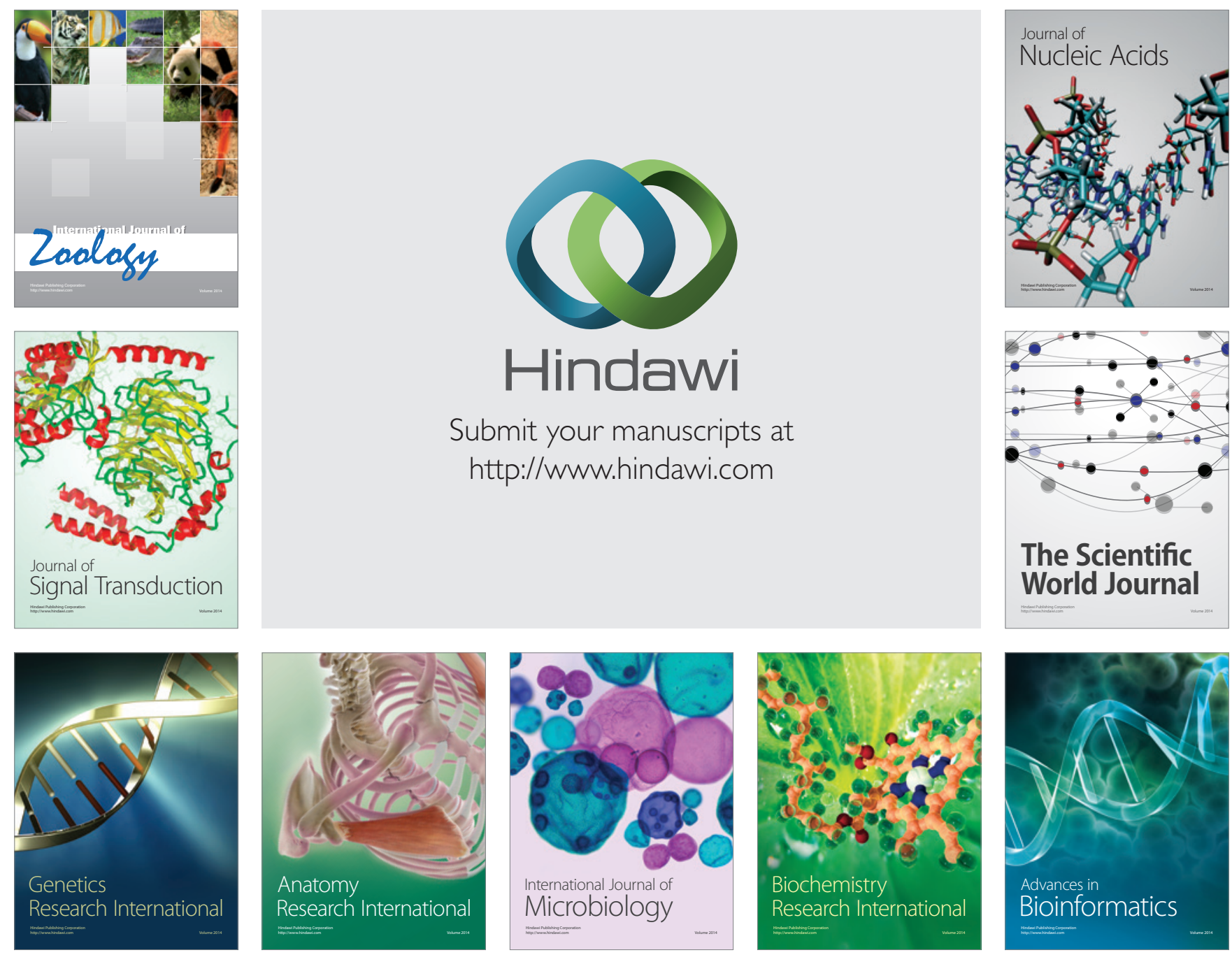

The Scientific World Journal
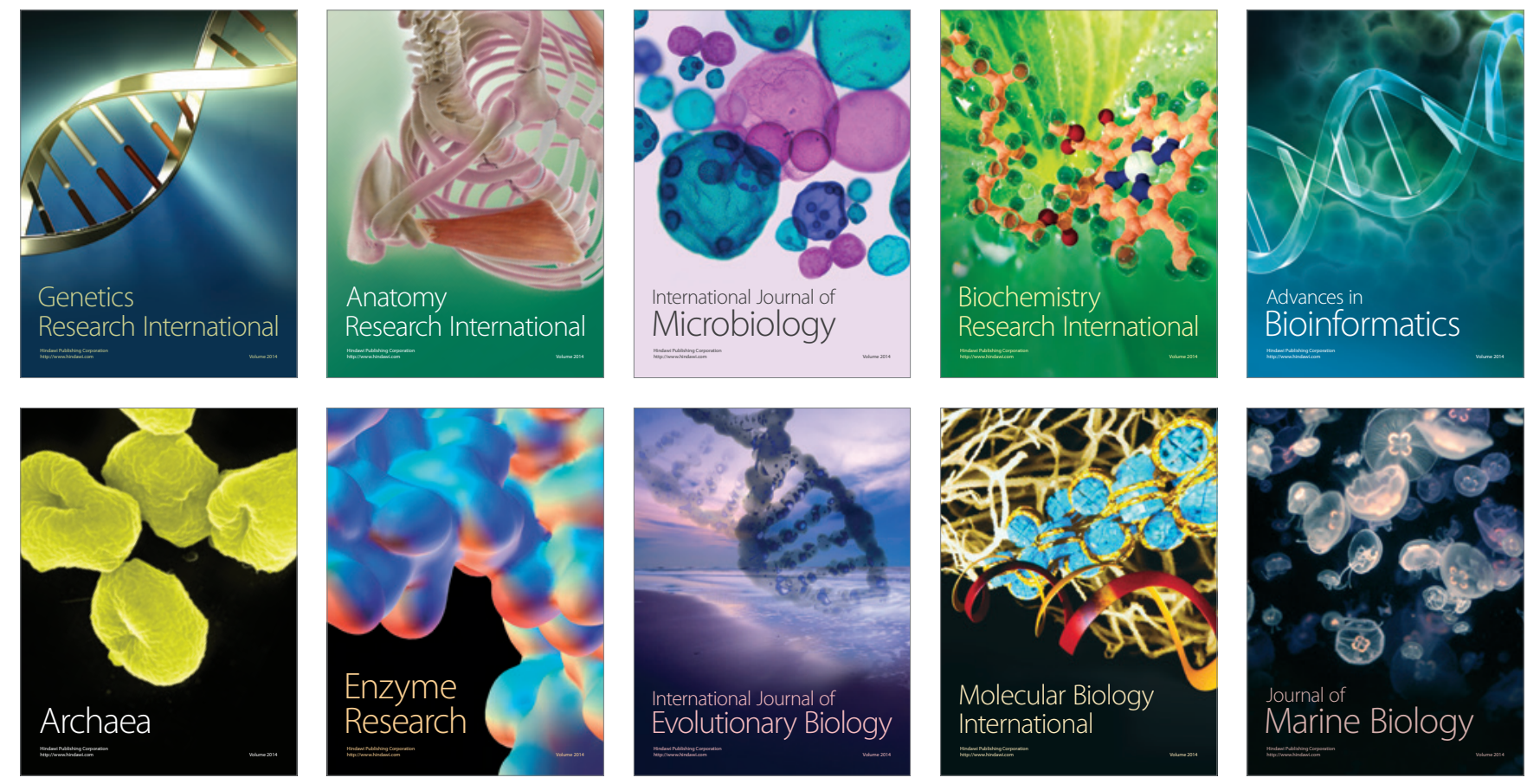